\title{
Enzymatic Biodegradation of Lignin-Cellulose Complex in Plant Origin Material
}

\author{
Regina VARNAITĖ, Vita RAUDONIENÉ *, Danguolė BRIDŽIUVIENĖ \\ Institute of Botany, Nature Research Center, Žaliuju Ežeru 49, LT-08406 Vilnius, Lithuania \\ Received 14 July 2010; accepted 11 December 2010
}

\begin{abstract}
Lignin and cellulose are chemically hardly destructible complex polymeric materials of organic origin. The main enzymes of fungi taking part in lignin degradation are phenoloxidases: lignin peroxidase, Mn-peroxidase and lacase, while in cellulose - endoglucanase. The aim of the investigation was to define the degradation of lignin and cellulose in the later stages of fungi cultivation, to determine the activity of phenoloxidases and endoglucanase and their abilities to degrade this complex. It was shown that the greatest lignin and cellulose degradation was measured after Galactomyces geotrichum 01230 and 60 cultivation days. Galactomyces geotrichum 012 showed the greatest peroxidase (68.13 a.u./g) and tyrosinase $(0.33$ c.u./g) activity, meanwhile laccase activity reached its peak (0.068 ext. coef.) after Sporotrichum pruinosum 60 cultivation days. The greatest endoglucanase activity was observed after Galactomyces geotrichum and Sporotrichum pruinosum in the course of whole cultivation period.

Keywords: rye straw, lignin, cellulose, phenoloxidases, endoglucanase, nitrogen.
\end{abstract}

\section{INTRODUCTION}

A large amount of plant waste is being continuously accumulated on the Earth. A part of the waste gets into the soil and an intensive destruction process starts. Intensity of this decay process depends on different environmental factors such as: species of plant, sort of soil, moisture, temperature and etc. In order to increase the efficiency of these metabolic processes, the scientific society is making strong efforts in this area. Moreover, the aim of the latest researches are oriented to intensify plant remnants decay and modify metabolites enriching the soil by useful biologically active substances and finding materials able to enrich forage and food by important biologically valuable additions $[1-3]$.

Different substrata basically consisting of cellulose, hemicellulose and lignin are the main nutrient source of microorganisms. Conversion process of plant waste is stimulated by various enzymes and based on the microorganism activity. The main enzymes of fungi taking part in lignin degradation are these phenoloxidases: lignin peroxidase, Mn-peroxidase and lacase, while in cellulose endoglucanase [4-8].

Phenoloxidases perform extortion of one electron from phenolic hydroxylic groups of lignin and consequently form the residues of phenoxide which could take part in various reactions.

In pursuance of biodegradation of plant remnants under solid-phase fermentation conditions the recent researchers have paid attention on enzymatic activity of micromycetes $[2,3,9,10]$.

Fungi play an important role in the biodegradation of various substrates rich in lignin and cellulose. Therefore, it is obvious that methods using these micromycetes for biotechnological purposes are quite promising. Microbiological degradation of lignin is foreseen as possibility to enrich fodder with proteins using it as a renewing raw-material [11-13].

\footnotetext{
*Corresponding author. Tel.: +370-5-2796640; fax.: +370-5-2729950. E-mail address: vita.raudoniene@botanika.lt (V. Raudonienè)
}

The aim of the investigation was to define the degradation of lignin and cellulose in the later stages of fungi cultivation, to determine the activity of phenoloxidases and endoglucanase and their abilities to degrade this complex.

\section{MATERIALS AND METHODS}

Fungal strains: Galactomyces geotrichum (Butl. et Petersen) Redhead et Malloch 012, Mortierella verticillata Lineum 156, Chaetomium globosum Kuze 067, Sporotrichum pruinosum Gilman et Abbott 145 that produce phenoloxidases and cellulases during lignincellulose complex degradation in plant remnants were used in the investigation.

Galactomyces geotrichum was isolated from soil (Kaunas, Botanical Garden), Mortierella verticillata from soil (timothy rhizosphere (Tr. Vokè)), Chaetomium globosum and Sporotrichum pruinosum from synthetic polymeric materials. The identification was performed following Domsch et al. [14].

Fungi are stored at the Laboratory of Biodeterioration Research, Institute of Botany, Nature Research Center.

Fungi were cultivated on the rye straw (Secale) under solid-state fermentation conditions, which mostly coincide with natural, and incubated at $28^{\circ} \mathrm{C} \pm 2{ }^{\circ} \mathrm{C}$ temperature. The estimation of peroxidase (PA), laccase (LA), tyrosinase (TA) and endoglucanase (EGA) activity and changes of lignin and cellulose content in plant remnants was fulfilled after 30 and 60 cultivation days.

The assay method of peroxidase activity is based on the colorimetric evaluation of the oxidation product of odianisidine in the presence of $\mathrm{H}_{2} \mathrm{O}_{2}$ [15]. The reaction mixture contained $0.1 \mathrm{ml}-0.5 \mathrm{ml}$ enzyme extract, $3 \mathrm{ml}$ o-dianisidine reagent $(50 \mathrm{ml}$ phosphate buffer $(0.4 \mathrm{M}$, $\mathrm{pH} 5.9) ; 2 \mathrm{ml} 1 \%$ o-dianisidine; distilled water $200 \mathrm{ml}$ ) and $0.2 \mathrm{ml} 0.05 \% \mathrm{H}_{2} \mathrm{O}_{2}$. Tests and controls were incubated at $20^{\circ} \mathrm{C}$ for $5 \mathrm{~min}$ in a water bath. The reaction was stopped by adding $50 \%$ of $\mathrm{H}_{2} \mathrm{SO}_{4}$ and the absorbance was read colorimetrically using a green filter. Activity was 
calculated according to the coefficient of micromolar ext., which is 0.0128. Peroxidase activity is expressed as activity units $\mathrm{g}^{-1}$ (a.u./g).

Laccase activity was measured according to Ravin and Harward [16]. The reaction mixture contained $0.1 \mathrm{ml}$ enzyme extract, $1 \mathrm{ml} 0.5 \%$ p-phenylenediaminechloride and $2 \mathrm{ml} 0.1 \mathrm{~N}$ acetate buffer, $\mathrm{pH} 6$. The reaction was stopped by adding $1 \mathrm{ml} 0.1 \%$ sodium azide solution. The absorbance was read at $530 \mathrm{~nm}$ using a SF-26 spectrophotometer. Laccase activity is expressed as extinction coefficient.

Tyrosinase activity was measured spectrophotometrically using a method based on the estimation of optical density of reaction products formed during oxidation of pyrocatechin (or other substratum) over given period [17]. The reaction mixture contained $0.5 \mathrm{ml}$ enzyme extract, $2 \mathrm{ml}$ phosphate buffer $(\mathrm{pH} 7.4)$ and $0.5 \mathrm{ml}$ pyrocatechin $(0.05 \mathrm{M})$ and the absorbance was read at $420 \mathrm{~nm}$ using a SF-26 spectrophotometer. Indications of spectrophotometer were recorded every $20 \mathrm{~s}$ for $2 \mathrm{~min}$. Enzyme activity is expressed as conditional units $\mathrm{g}^{-1}$ (c.u./g).

Endoglucanase activity was estimated with $\mathrm{Na}-$ carboximetilcellulose (Na-CMC) [15]. $1 \mathrm{ml} 1 \% \mathrm{Na}-\mathrm{CMC}$ was placed in test-tube containing $1 \mathrm{ml}$ filtrate of suspension and this compound was incubated at a temperature of $40^{\circ} \mathrm{C}$ for $0.5 \mathrm{~h}$ in a thermostat. After incubation the amount of reducible substance was estimated in $1 \mathrm{ml}$ reaction compound.

The amount of lignin in the plant remnants was evaluated following the method of Chudiakova [18]. $2 \mathrm{~g}$ of plant material were placed in $300 \mathrm{ml}$ flasks containing $60 \mathrm{ml}-70 \mathrm{ml} 2 \% \mathrm{HCl}$ and boiled for $2 \mathrm{~h}$. The content was then filtered, washed with water until acid reaction ceased, and with acetone until the filtrate became white. The plant raw material was then dried and transferred into flasks containing $7 \mathrm{ml} 72 \% \mathrm{H}_{2} \mathrm{SO}_{4}$. Hydrolysis was allowed to proceed for $2.5 \mathrm{~h}$ at $20^{\circ} \mathrm{C}-23^{\circ} \mathrm{C}$ with periodical shaking. Water $(93 \mathrm{ml})$ was then poured into each flask and the content boiled for $1 \mathrm{~h}$ after fitting with a return condenser. After filtration, the filtrate was washed with $\mathrm{NaCl}$ solution $\left(0.5 \mathrm{~g} \mathrm{~L}^{-1}\right)$ in order to eliminate acid. The filter with lignin was dried at $105^{\circ} \mathrm{C}$ for $4 \mathrm{~h}$ and weighed. Loss in lignin was compared with the corresponding amount in control straw.

Amount of cellulose in the plant remnants was evaluated following Kürschner's and Hafer's method [17]. $2 \mathrm{~g}$ of plant material were placed in $300 \mathrm{ml}$ flasks containing $30 \mathrm{ml}-50 \mathrm{ml}$ mixture of $\mathrm{HNO}_{3}$ and $\mathrm{C}_{2} \mathrm{H}_{5} \mathrm{OH}$ and boiled for $1 \mathrm{~h}$. The content were then filtered and washed with alcohol. The plant raw material was then dried and transferred into flasks containing $50 \mathrm{ml} 0.3 \mathrm{M}$ $\mathrm{NaOH}$ and boiled for $1 \mathrm{~h}$ after fitting with a return condenser. After filtration, the filtrate was washed with $\mathrm{H}_{2} \mathrm{O}$. The filter with cellulose was dried at $105^{\circ} \mathrm{C}$ for $4 \mathrm{~h}$ and weighed.

The total nitrogen $(\mathrm{N})$ content in a product after cultivation of micromycetes was evaluated with an automatic "Kontoflo" analyzator. Mineralization of the plant raw material was performed by the Kjeldal method [17]. The ratio of a sample and mineralizing acid was $1: 20$. The amount of proteins was found by multiplication of the total nitrogen by 6.25 .
The obtained results were processed using Microsoft Excel XP, Statistics 5.1.

\section{RESULTS AND DISCUSSION}

Some fungi during growth process on plant remnants use lignin, cellulose and other polysaccharides as a source of carbon [19], therefore the ability of the selected fungi to grow and utilize remnants of rye straw and to degrade lignin and cellulose was investigated.

Lignin and cellulose are chemically hardly destructible complex polymeric materials of organic origin, which have accumulated an enormous amount of photosynthetic energy [20].

The lignin content of the control straw was $16.2 \%$ (Fig. 1). The statistic data show that all of the investigated fungi reduced reliably the quantity of lignin in rye straw in the course of whole cultivation period. The greatest lignin degradation was measured after Galactomyces geotrichum 30 and 60 cultivation days. The lignin content decreased 1.88 and 1.93 times respectively in comparison with the control straw.

The major lignin degradation (to $9.8 \%$ ) was measured after Sporotrichum pruinosum 60 cultivation days. It was 1.65 times lower than in the control. The minimum decrease of lignin was observed after Chaetomium globosum cultivation: after 30 and 60 days it was respectively 1.12 and 1.14 times lower in comparison with the control.

It was shown that fast decay of lignin goes on in later stage of lignin-cellulose complex degradation. During cultivation process of fungi Postia placenta and Gloeophyllum trabeum carbohydrates dominate until $40^{\text {th }}$ day of cultivation, but after 50 days spectrum of methoxyl and aromatic ring of lignin increases [21].

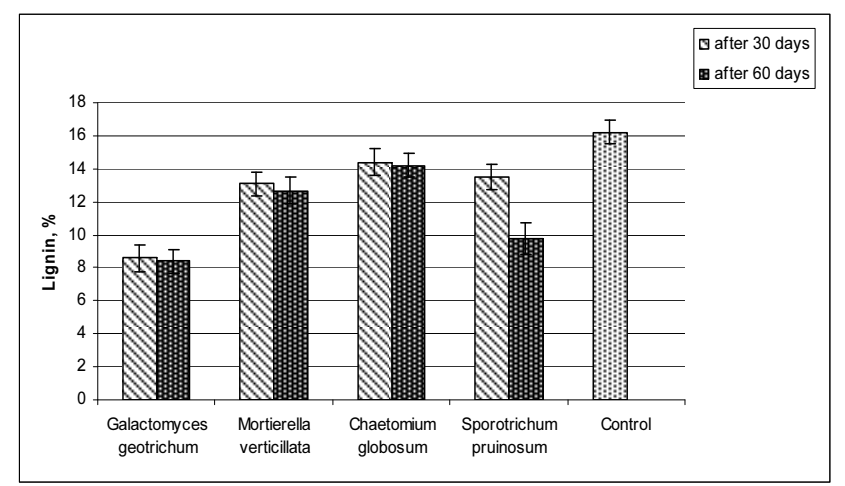

Fig. 1. The change in the amount of lignin in rye straw after fungal cultivation

The obtained results showed (Fig. 2) that the cellulose content of the control rye straw was $52.7 \%$. The statistics show that after cultivation of all fungi amount of cellulose reliably decreased in comparison with the control during the cultivation course. The content of cellulose in rye straw changed most of all after Galactomyces geotrichum 30 cultivation days (decreased 2.76 times in comparison with the control). Fungus Mortierella verticillata decreased the content of cellulose 2.02 times.

The lowest content of cellulose $(5.48 \%)$ was defined after Galactomyces geotrichum 60 cultivation days. It was 9.6 times lower than in the control. Fungi Sporotrichum 
pruinosum and Mortierella verticillata in this period of cultivation decreased the content of cellulose respectively 2.9 and 2.7 times in comparison with the control.

Various enzymes produced during functional activity of microorganisms catalyze the processes of plant remnant conversion. The complex polymers from plant remnants affected by the phenoloxidases and endogluconases began to decompose, and consequently many compounds of phenol and neutral origin appear.

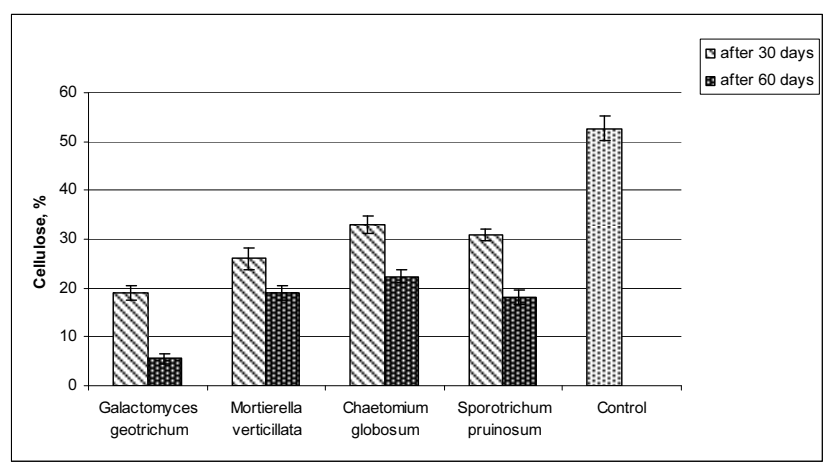

Fig. 2. The change in the amount of cellulose in rye straw after fungal cultivation

The obtained results showed (Fig. 3) that the greatest peroxidase activity (68.13 a.u./g) was observed after 30 days of Galactomyces geotrichum cultivation. In the further course of cultivation (60 days) this activity decreased to 32 a.u./g.

Regularity of change of the peroxidase activity of other investigated fungi was different: Mortierella verticillata increased from $9.68 \mathrm{a} . \mathrm{u} . / \mathrm{g}$ to $18.75 \mathrm{a} . \mathrm{u} . \mathrm{g}$, Chaetomium globosum - from 3.13 a.u./g to 13.12 a.u./g. This activity after Sporotrichum pruinosum 30 cultivation days did not manifest at all but after 60 days it was 14.06 a.u./g.

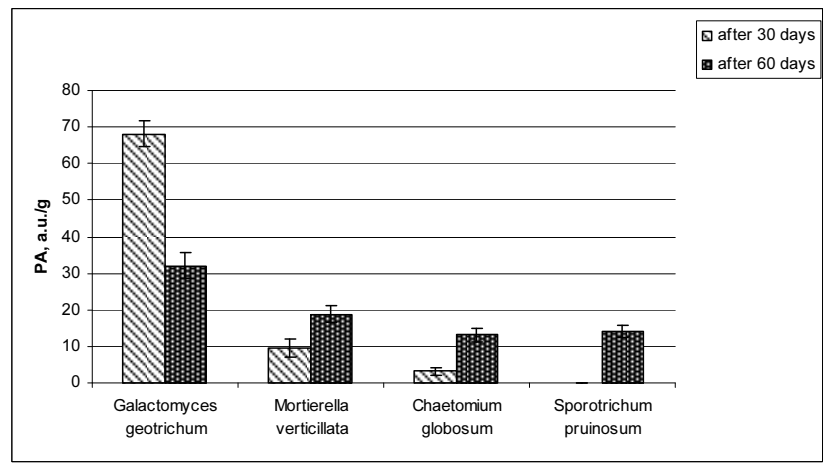

Fig. 3. Peroxidase activity (PA) of fungi after 30 and 60 days of cultivation under solid-phase fermentation conditions

Regularity of change of the tyrosinase activity of fungi was a little bit different from peroxidase (Fig. 4). In contrast to peroxidase, the tyrosinase activity after Galactomyces geotrichum 60 days of cultivation increased to 0.33 c.u./g (2.5 times in comparison with 30 days). The tyrosinase activity of Sporotrichum pruinosum and Mortierella verticillata was low during the whole period of cultivation. The tyrosinase activity after Chaetomium globosum 60 days of cultivation decreased (1.7 times).
Destruction metabolites, which have formed during degradation of plant remnants, affect tyrosinase (and other enzyme) activity: some of them stimulated, others inhibited. Therefore, enzyme activity varied in the course of cultivation $[22,23]$.

The laccase activity of studied fungi was different (Fig. 5). Galactomyces geotrichum and Chaetomium globosum laccase activity reached its peak after the period of 30 days of cultivation ( 0.005 ext. coef. and 0.05 ext. coef. respectively), while Mortierella verticillata and Sporotrichum pruinosum - after 60 days (0.03 ext. coef. and 0.068 ext. coef. respectively). Kluczek-Turpeinen et al. [24] ascertained that the highest laccase activities were observed after 4 weeks of Paecilomyces inflatus cultivation on wheat straw.

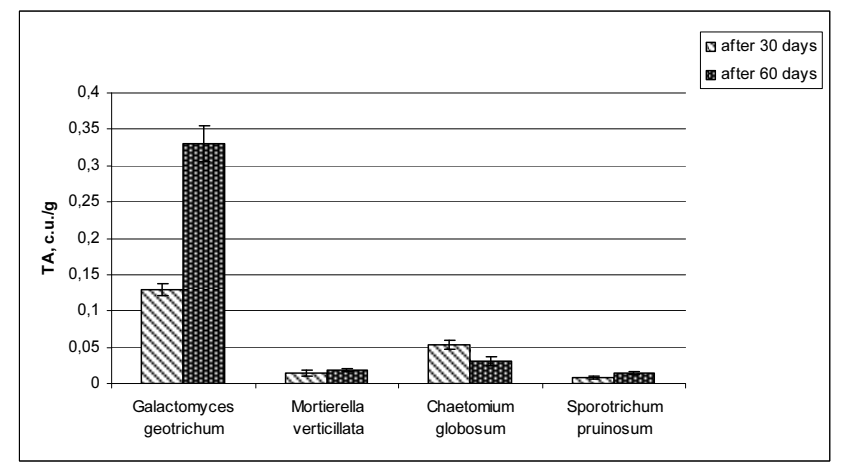

Fig. 4. Tyrosinase activity (TA) of fungi after 30 and 60 days of cultivation under solid-phase fermentation conditions

Some authors [25] showed that wheat bran appeared to be the best growth substrate for fermentation of Cerrena unicolor, enabling a very high accumulation of laccase (87.450 IU/L on day 7) in culture liquid. It is worth noting that in most cases only increased fungi growth and biomass in the presence of additional nitrogen accounts for the higher level of laccase activity [26].

The nature and chemical composition of lignocellulosic material is one of the main factors determining the expression of fungi lignocellulolytic potential as well as the ratio of individual enzymes in lignocellulolytic system. For example, Pleurotus dryinus maximal laccase activity was equal to $119,195,794$, and $4103 \mathrm{U} / \mathrm{L}-1$ in $\mathrm{SF}$ of milled tree leaves, banana, apple, and mandarin peels, respectively $[13,26]$.

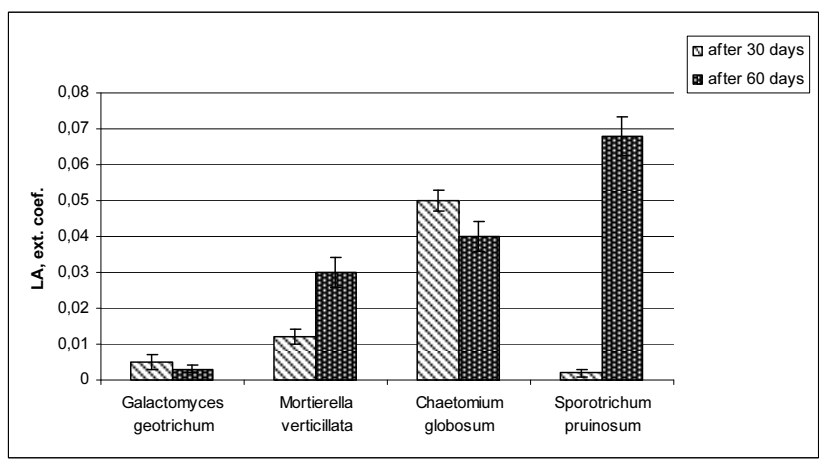

Fig. 5. Laccase activity (LA) of fungi after 30 and 60 days of cultivation under solid-phase fermentation conditions 
Cellulolytic enzymes play an important role in natural biodegradation processes in which plant lignocellulose materials are efficiently degraded by fungi.

The endoglucanase activity of all investigated fungi cultivated under solid-state fermentation conditions after 30 days of cultivation range from $32.6 \%$ to $89.2 \%$, after 60 days - was higher and range from $59.9 \%$ to $141.9 \%$ (Fig. 6). The greatest endoglucanase activity was observed after Galactomyces geotrichum and Sporotrichum pruinosum during the whole period of the cultivation; on the $30^{\text {st }}$ day of the cultivation it was respectively $89.2 \%$ and $78.9 \%$, while on the $60^{\text {st }}$ day -141.9 and $123.1 \%$.

It was found that decay products of lignin-cellulose complex influenced cellulase activity. Endoglucanase activity decreased sharply when during the destruction of lignin-cellulose complex the amount of carbohydrate in medium increased (30 mM-40 mM) [22].

Other authors observed that Aspergillus, Penicillium and Fusarium generus species have the highest endoglucanase activities during their cultivation on the medium with husk of sunflower seeds, wheat bran, leaves and stems of Z. marina and rye straw [27]. During solidstate fermentation of tree leaves by fungi of genus Pleurotus (basidiomycetes), endoglucanase activity varied from $0.5 \mathrm{U} \mathrm{mL}-1$ to $26.0 \mathrm{U} \mathrm{mL}-1$ [26].

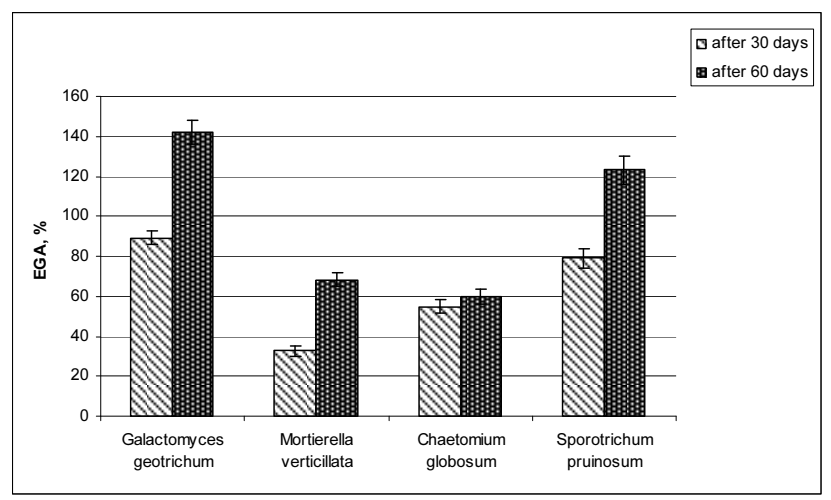

Fig. 6. Endogluconase (EGA) activity of fungi after 30 and 60 days of cultivation under solid-phase fermentation conditions

The total nitrogen of the control rye straw make up $1.05 \%$. The greatest content of the total nitrogen was estimated after Galactomyces geotrichum 30 days of cultivation on the rye straw $(3.27 \%)$. It was 3.13 times higher than in the control (Fig. 7). The similar amount of the total nitrogen was estimated after Sporotrichum pruinosum and Chaetomium globosum cultivation (respectively $2.34 \%$ and $2.4 \%$ ). The least amount of the total nitrogen $(1.86 \%)$ was estimated after Mortierella verticillata cultivation, but it was higher than in control.

The data proved that sufficient nitrogen concentrations contained in plant raw materials was needed to ensure both fungi growth and enzyme synthesis. However, the yield of lignocellulolytic enzymes depended on fungi and lignocellulosic substrate, supplemented with additional nitrogen sources [26].

The obtained results showed that the straw was most significantly enriched with proteins (same as total nitrogen) by Galactomyces geotrichum (20.5) and
Chaetomium globosum (15.0\%). Their content was respectively 3.12 and 2.28 times higher in comparison with the control.

The total protein content increased together with biomass. However, the total increase of mycelium biomass not necessary was followed by increase of protein content [28].

The content of the total nitrogen plays an important role in the degradation of plant remnants. The higher total nitrogen and less $\mathrm{C}: \mathrm{N}$ ratio the decay process go on intensively.

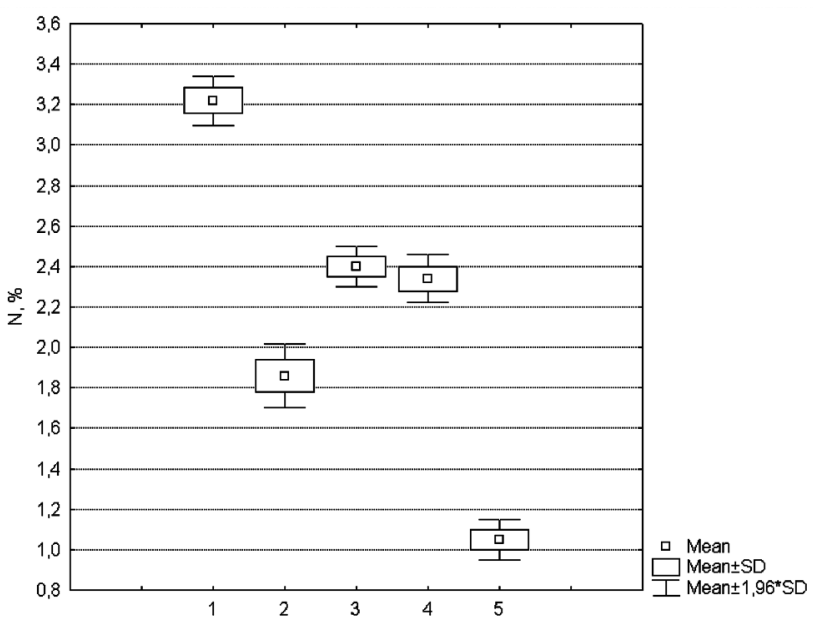

Fig. 7. Total nitrogen in rye straw after 30 days of cultivation of fungi: 1 - Galactomyces geotrichum, 2 - Mortierella verticillata, 3 - Chaetomium globosum, 4 - Sporotrichum pruinosum, 5 - control

\section{CONCLUSIONS}

1. The ability of fungi to utilize lignin-cellulose complex in plant remnants is different and depend on their peculiarities and duration of fungi cultivation. Some fungi can carry out deeper hydrolysis of this complex in a short term, meanwhile some of them need much time to induce small changes in the structure of this complex. The greatest lignin and cellulose degradation was measured after Galactomyces geotrichum 30 and 60 cultivation days.

2. Enzymatic activities of fungi depended on their peculiarities and cultivation time. The greatest peroxidase (68.13 a.u./g) and tyrosinase (0.33 c.u./g) activity was observed after Galactomyces geotrichum cultivation, meanwhile laccase activity reached its peak (0.068 ext. coef.) after Sporotrichum pruinosum 60 cultivation days. The greatest endoglucanase activity was observed after Galactomyces geotrichum and Sporotrichum pruinosum in the course of whole cultivation period.

3. The maximum content of the total nitrogen was estimated after Galactomyces geotrichum and Chaetomium globosum cultivation in rye straw.

\section{REFERENCES}

1. Reid, I. D. Solid State Fermentations for Biological Delignification Enzyme Microbial Technology 11 1989: pp. $786-803$. 
2. Kelley, J. Upgrading of Waste Cereal Straws Outlook of Agriculture 21 (2) 1992: pp. 105-108.

3. Varnaitė, R. Bioconversion of Rye Straw by Micromycetes Biologija 4 2001: pp. 34-36.

4. Yoshida, S., Yonehara, S., Minami, S., Ha, H., Iwahara, K., Watanabe, T., Honda, Y., Kuwahara, M. Production and Characterization of Ligninolytic Enzymes of Bjerkandera adusta Grown on Wood Meal/Wheat Bran Culture and Production of These Enzymes Using a RotarySolid Fermenter Mycoscience 37 1996: pp. 417-425.

5. Ortega, N., Busto, M. D., Perez-Mateos, M. Kinetics of Cellulose Saccharification by Trichoderma reesei Cellulases International Biodeterioration and Biodegradation 47 (1) 2001: pp. $7-14$.

6. del Pilar Castillo, M., Ander, P., Stenstrom, J. Lignin and Manganese Peroxidase Activity in Extracts from Straw Solid Substrate Fermentations Biotechnology Techniques 11 (9) 1997: pp. $701-706$.

7. Tanaka, H., Koike, K., Itakura, S., Enoki, A. Degradation of Wood and Enzyme Production by Ceriporiopsis subvermispora Enzyme and Microbial Technology 45 2009: pp. 384-390.

8. Bridžiuvienė, D., Lugauskas, A. Evaluation of the Efficiency of Some on Offers Wood Preservatives Materials Science (Medžiagotyra) 9 (4) 2003: pp. 363-367.

9. Hernandez-Coronado, M. J., Hernandez, M., Centenera, F., Perez-Leblic, M. I., Ball, A. S., Arias, M. E. Chemical Characterization and Spectroscopic Analysis of the Solubilization Products from Wheat Straw Produced by Streptomyces Strains Grown in Solid-State Fermentation Microbiology 143 1997: pp. 1359-1367.

10. Reid, I. D., Paice, M. G. Effects of Manganese Peroxidase on Residual Lignin of Softwood Kraft Pulp Applied and Environmental Microbiology 64 (6) 1998: pp. 2273-2274.

11. Babickaja, V. G. Enzymatic Lignin Degradation in Plant Substrates by Mycelial Fungi Engineering Biochemistry and Microbiology 30 (6) 1994: pp. $827-835$ (in Russian).

12. Daljit, S. Arora. Biodelignification of Wheat Straw by Different Fungal Associations Biodegradation 6 (1) 1995: pp. 57-60.

13. Petre, M., Teodorescu, A., Dicu, G. The Growing Effect of Vineyard and Winery Wastes on the Production of Mycelia and Fruit Bodies of Edible and Medicinal Fungi International Journal for Medicinal Mushrooms 7 (3) 2005: pp. $444-445$.

14. Domsch, K. H., Gams, W., Anderson, T. H. Compendium of Soil Fungi. Academic Press, London, 1980.

15. Bilai, V. I. Methods of Experimental Mycology. Kiev, Naukova dumka, 1982 (in Russian).
16. Ravin, H., Harward M. Rapid Test for Hepatolenticular Degeneration The Lancet 1965: pp. 726-727.

17. Jermakov, A. I., Arasimovitsh, V. V., Jarosh, N. P., Peruanskij, U. A., Lukovnikova, G. A., Ikonnikova, M. I. Determination of Polyphenoloxidase Activity Methods of Plant Biochemical Research Leningrad, 1987 (in Russian).

18. Chudiakova, Ch. K. Determination of the Lignin Content in Fodder and Green Crop Agricultural Biology 8 1984: pp. $120-124$ (in Russian).

19. Rodriguez, A., Perestelo, F., Carnicero, A., Regalado, V., Perez, R., de la Fuente, G., Falcon, M. A. Degradation of Natural Lignins and Lignocellulosic Substrates by Soilinhabiting Fungi Imperfecti FEMS Microbiology Ecology 21 (3) 1996: pp. 213-219.

20. Blanchette, R. A. A Review of Microbiol Deterioration Found in Archaeological Wood from Different Environments International Biodeterioration and Biodegradation 46 2000: pp. $189-204$.

21. Irbe, I., Andersone, I., Andersons, B., Chirkova, J. Use 13 CNMR, Sorption and Chemical Analyses for Characteristics of Brown-Rotted Scots Pine International Biodeterioration and Biodegradation 47 2001: pp. 37-45.

22. Todorovic, R., Grujic, S., Matavulj, M. Effect of Reaction End-Products on the Activity of Cellulolytic Enzymes and Xylanase of Trichoderma harzianum Microbios Letters $36(143-144)$ 1987: pp. $113-119$.

23. Varnaitè, R., Raudonienė, V. Biodegradation of Plant Remnants by Micromycetes Biologija 3 2004: pp. 43-46.

24. Kluczek-Turpeinen, B., Maijala, P., Hofrichter, M., Hatakka, A. Degradation and Enzymatic Activities of Three Paecilomyces inflatus Strains Grown on Diverse Lignocellulosic Substrates International Biodeterioration and Biodegradation 59 2007: pp. 283-291.

25. Rebhun, M., Hadar, Y. Use of Agro-Industrial Waste for Production of Laccase and Manganese Peroxidase from White-Rot Basidiomycetes International Journal for Medicinal Mushrooms 7 (3) 2005: pp. 457-459.

26. Songulashvili, G. G., Elisashvili, V., Penninckx, M., Metreveli, E., Hadar, Y., Aladashvili, N., Asatiani, M. Bioconversion of Plant Raw Materials in Value-Added Products by Lentinus edodes (Berk.) Singer and Pleurotus spp. International Journal for Medicinal Mushrooms 7 (3) 2005: pp. $457-459$.

27. Olishevska, S. V., Ayzenberg, V. L., Vasylevska, A. I., Zhdanova, N. M., Kurchenko, I. M., Kapichon, G. P., Artyshkova, L. V., Nakonechna, L. T. EndoglucanaseProducing Micromycetes Capable of Plant Wastes Degrading Eksperimental Work 81 (5) 2009: pp. 100-105.

28. Marchant, R. Wall Composition of Monokarions and Dikaryons of Coprinus cinereus Journal of General Microbiology 106 1978: pp. 195-199. 